\title{
The roles of radiology and ESR in the diagnosis of tuberculosis in young military males in Iraq
}

\author{
Hussein M. Jumaah

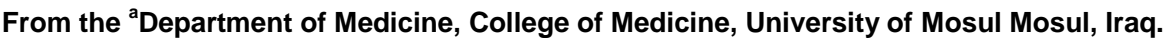 \\ Correspondence: Hussein M. Jumaah.dhussien_mj@yahoo.com.
}

(Ann Coll Med Mosul 2013; 39 (2): 182-185).

Received: $27^{\text {th }}$ Dec. 2012; Accepted: $29^{\text {th }}$ Sept. 2013.

\section{ABSTRACT}

Objective: To describe the radiological findings of active pulmonary tuberculosis (PTB) and /or tuberculous pleural effusion (TPE) in adult males, to determine the site and extent of lesions and test the significance of the erythrocyte sedimentation rate (ESR) in these patients.

Patients and methods: A retrospective observational study of two hundred and sixty two military male patients with PTB and /or TPE with their age ranging from 25 to 40 years. Data were collected from the medical records at the Mosul General Hospital (which was a military hospital prior to 2003), during the period from July1995 to June 2002.

Results: The radiologic lesions of PTB were most commonly seen in the upper zones, (74\% P-value $0.0001)$. TPE was more commonly involving the right side $(64 \%)$. ESR value was found to be elevated in most of the patients (84\%).

Conclusion: PTB was seen mostly in the upper zones, TPE has more predilections to the right side. The ESR is still a useful test in the diagnosis of tuberculosis.

$$
\begin{aligned}
& \text { التدرن لاى الشباب من العسكريين الأكور في العراق } \\
& \text { حسبن محمد جمعة } \\
& \text { فرع الطب، كلية الطب، جامعة الموصل، الموصل، العراق جمة }
\end{aligned}
$$

الأهداف: لوصف العلامات الثعاعية للتدرن الرئوي الفعال وإنصباب الجنب التدرني عند الذكور البالغين، ولتحديد مدى وموقع

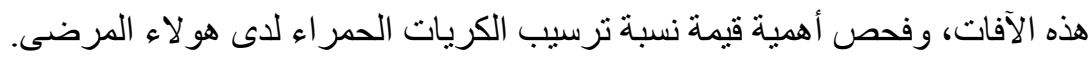

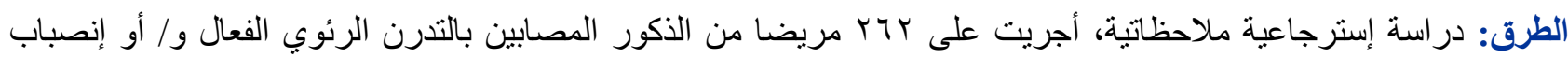
الجنب التدرني. تر اوحت أعمار هم بين هب ـ • ـ سنة. جمعت المعلومات من الوثائق الطبية في مستشفى الموصل العام (و التي كانت

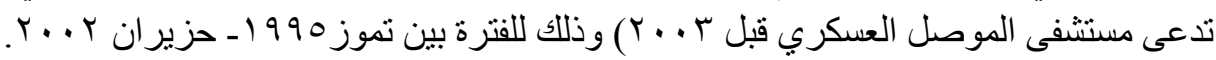

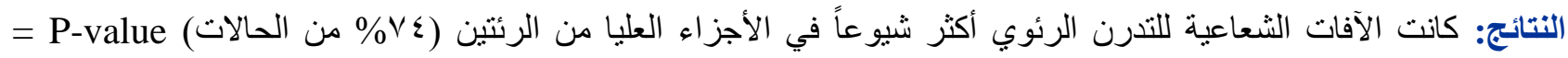

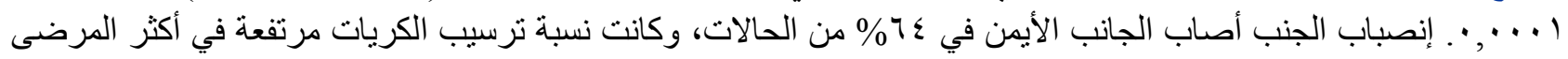
$(\% \wedge \varepsilon)$ الإستنتاج: كانت أكثر حالات التدرن الرئوي تصيب الفصوص العليا من الرئتين. وإنصباب الجنب كان أكثر حدوثاً في الجانب الأيمن. وكانت نسبة ترسيب الكريات مفيدة في تشخيص التدرن الفعال و إنصباب الجنب التدرني .

\section{INTRODUCTION}

$\mathrm{T}$ uberculosis (TB) is a leading infectious killer disease of adults. It is estimated that Mycobacterium Tuberculosis infects some 50 to 100 million people every year. Ten to twenty million people develop overt disease and about 3 million people die every year. ${ }^{1}$

PTB commonly affects the upper lung fields; lower lung field tuberculosis is also not uncommon. ${ }^{1}$ TB bacilli primarily attack the lungs in more than $80 \%$ of the cases, leading to primary 
pulmonary tuberculosis. Extra-pulmonary tuberculosis (EPTB) occurs in less than $20 \%$ of cases and affects various organs such as lymph nodes, meninges, intestine, bone and joints. ${ }^{2}$

Although the diagnosis of PTB should be established by the finding of Mycobacterium tuberculosis in the sputum, in practice this criterion is often not satisfied. In some instances the diagnosis is based only upon the finding of a suggestive radiological picture. The radiographs may show the characteristic findings of infiltrates with cavitation in the upper and middle zones of the lungs. ${ }^{3}$

Often additional investigations are employed to aid the diagnosis. These include measurement of the ESR and the tuberculin test. It is commonplace for the ESR to be included in the assessment of patients suspected of having tuberculosis. ${ }^{3}$ This investigation is widely thought to reflect the activity of a tuberculous lung lesion. ${ }^{3}$

Sixty percent of patients with extrapulmonary manifestations of TB have no evidence of pulmonary infection on chest radiograph or sputum culture. ${ }^{4}$ The hallmark of EPTB histopathology is the epithelioid granulomata with or without caseation or multinucleated giant cells. ${ }^{5}$

The investigation of pleural effusion has been greatly assisted by advancements in pleural fluid analysis. In the case of TPE, diagnosis traditionally requires the demonstration of acid fast bacilli, which are rarely seen, in the pleural fluid using microbiological or histological/cytological techniques. In recent years, there has been progress in pleural fluid analysis in suspected tuberculous effusions, with particular interest in adenosine deaminase and Interferon- $y$ release assays (IGRA). These individual tests are quite sensitive and specific. ${ }^{6}$

TPE is one of the most common forms of EPTB. The immediate cause of TPE is a delayed hypersensitivity response to mycobacterium antigens in the pleural space. ${ }^{7}$

The highest diagnostic yield for TPE was obtained by histology of pleura in (85\%), followed by culture of pleural biopsy (37\%) and pleural fluid culture $(36 \%){ }^{8}$ Closed pleural biopsy remains the most sensitive diagnostic method. ${ }^{9}$

\section{Aim of the study:}

1.To assess radiologic features of PTB \& TPE, and to determine the site and extent of these lesions.
2. To determine the significance of ESR.

\section{PATIENTS AND METHODS}

A retrospective observational study was adopted. Two hundred and sixty two military male patients (from various areas in Iraq) with PTB and TPE diagnosed and managed at Mosul Military Hospital were enrolled in the study. The age of the patients ranged between 25 and 40 years.

Chest x-ray (CXR) localization was interpreted by using zone classification. Upper-mid zones are separated by a horizontal line passing at the level of lower margin of second and fourth ribs respectively and lower zone from $4^{\text {th }}$ rib to diaphragm.

The inclusion criteria included patients with PTB. The diagnosis was based on a positive CXR and positive sputum for AFB. Patients with TPE should have positive CXR, pleural aspiration cytology, and positive pleural biopsy (done with the Abrams needle).

CXRs were analyzed by radiologist for the diagnosis and localization of the PTB and TPE.

The ESR has been used for our patients and the normal value is $(0-10 \mathrm{~mm} / \mathrm{hr})$.

The exclusion criteria included; patients with negative sputum for AFB, inconclusive pleural biopsy, and patients with poorly localized pulmonary disease (based on radiological features).

\section{The statistical analysis}

Data analysis made by using Minitab software program version 14.1. Z-test for two proportions was applied to compare between relevant proportions. Chi-square for categorized data was also pertained. P-value $<0.05$ was considered significant during data analysis.

\section{RESULTS}

One hundred and sixty two patients were found to have PTB (61.8\%). The CXR showed that the lesions were commonly seen in the upper zones in (74\%) as in Table 1.

PTB lesion was localized to one lung in 102 patients. It was the right lung that was more commonly involved in $64(62.7 \%)$ of cases, while the left lung was affected in 38 cases $(37.3 \%)$ ( $P$ value $=0.0001$, highly significant).

The upper zones were affected more often than the middle and lower zones, with highly significant 
difference between them with (P-value 0.0001) as in Table 1.

TPE was found in 100 patients (38.1\%). The percentage of localization of pleural effusion indicates that the right pleural space was more commonly involved in (64\%) of patients with highly significant difference (P-value 0.0001) when compared with left sided (32\%) or bilateral involvement (4\%) as in Table 2.

The values and the percentage of ESR of all patients indicate that the range of $75-100 \mathrm{~mm} / \mathrm{hr}$ is the highest in frequency among all patients studied as in Table 3. ESR less than $10 \mathrm{~mm} / \mathrm{hr}$ was seen in $19.4 \%$ of cases. This means that normal ESR could be seen in an active PTB. ESR was elevated in the remaining $80.6 \%$ of cases $P$ value $=0.000$. ESR was most commonly in the range of $75-100 \mathrm{~mm} / \mathrm{hr}$.

Table 1. The localization of CXR finding in patients with PTB $(n=162)$.

\begin{tabular}{lcccc}
\hline $\begin{array}{c}\text { The } \\
\text { lung }\end{array}$ & $\begin{array}{c}\text { Upper } \\
\text { No. }(\%)\end{array}$ & $\begin{array}{c}\text { Middle } \\
\text { No. (\%) }\end{array}$ & $\begin{array}{c}\text { Lower } \\
\text { No. } \%)\end{array}$ & $\begin{array}{c}\text { P- } \\
\text { value }\end{array}$ \\
\hline Right & $44(36.7)$ & $\begin{array}{c}10 \\
(43.5)\end{array}$ & $10(52.6)$ & \\
\hline Left & $26(21.7)$ & $6(26.1)$ & $6(31.6)$ & $\begin{array}{c}0.266 \\
\mathrm{a}\end{array}$ \\
Both & $50(41.7)$ & $7(30.4)$ & $3(15.8)$ & \\
\hline Total & $120(74 \%)$ & $\begin{array}{c}23 \\
(14.2 \%)\end{array}$ & $\begin{array}{c}11.7 \%) \\
\text { (11. }\end{array}$ & $\begin{array}{c}0.0001 \\
b\end{array}$ \\
\hline
\end{tabular}

${ }^{\mathrm{a}}$ Chi-square was used.

${ }^{\mathrm{b}}$ Z-two proportion between the upper zone and the middle and the lower combined $(25.9 \%)$ was used.

Table 2. The percentage of localization of pleural effusion.

\begin{tabular}{lcc}
\hline The pleural space & Number and (\%) & P-value $^{\text {a }}$ \\
\hline Right & $64=64 \%$ & --- \\
Left & $32=32 \%$ & 0.0001 \\
Both & $4=4 \%$ & 0.0001 \\
\hline Total & $100=100 \%$ & \\
\hline
\end{tabular}

${ }^{a}$ Z-two proportion was used.

Table 3. The values and the percentage of ESR of all patients $(\mathrm{n}=262)$.

\begin{tabular}{ccccc}
\hline Normal ESR & \multicolumn{4}{c}{ High ESR titer } \\
\hline $\begin{array}{c}<10 \mathrm{~mm} / \mathrm{hr} \\
\text { No. }(\%)\end{array}$ & $\begin{array}{c}11-50 \\
\text { No. (\%) }\end{array}$ & $\begin{array}{c}51-75 \\
\text { No. }(\%)\end{array}$ & $\begin{array}{c}76-100 \\
\text { No. }(\%)\end{array}$ & $\begin{array}{c}>100 \\
\text { No. }(\%)\end{array}$ \\
\hline $51(19.4 \%)$ & 49 & 41 & $61(23.2)$ & 60 \\
& $(18.7)$ & $(15.6)$ & & $(22.9)$ \\
\hline
\end{tabular}

$\mathrm{P}=0.000$ between the normal ESR and abnormal ESR proportions by using Z-two proportion test.

\section{DISCUSSION}

Tuberculosis is a serious health problem worldwide and constitutes the main infectious cause of death. ${ }^{10}$ In our study the patients were adult males and the results were comparable to some other studies done in other countries.

CXR plays an important role in the clinical diagnosis of PTB. ${ }^{11,12}$ Our study indicates that the upper zones were affected (74\%) more than the middle and lower zones, with highly significant difference between them. The right lung was involved in $62.7 \%$ of cases of unilateral lesions, compared with the left lung 37.3\% P-value $=0.0001$ (highly significant difference). These findings were consistent with those of Zuber et al, where the right lung was affected in $56 \%$ as opposed to the left lung which was seen in $26 \% .{ }^{1}$ Reasons for higher predilection for right lung are not well understood, may be attributed to anatomical factors. Moreover, there is a higher incidence of right sided hilar lymphadenopathy in Asians. ${ }^{13}$ These lymph nodes may rupture through a bronchus and can cause lower zone infection. ${ }^{14}$

Involvement of the lower lung field was seen in nearly $(11.7 \%)$ which is the same as in Zuber Ahmad study. ${ }^{1}$

TB can involve any organ system in the body. Although PTB is the most common presentation, EPTB still constitutes an important clinical problem. EPTB, by definition, is the isolated occurrence of TB at body sites other than the lung.

Extrapulmonary organ involvement by TB is estimated in $10 \%-34 \%$ of patients who are not infected with human immunodeficiency virus (HIV) whereas the frequency is about $50 \%-70 \%$ in patients infected with HIV. ${ }^{15}$ The most common sites of extrapulmonary involvement were reported as pleura and lymph node. ${ }^{16}$

TPE is most frequently seen in adolescents and adults as a complication of primary TB. The effusion generally develops on the same side as the initial infection and is typically unilateral. ${ }^{17} \mathrm{TPE}$ that occurs in the absence of radiologically apparent TB may be a sequel to a primary infection 6-12 weeks previously or it may represent reactivation. ${ }^{18}$ The pathogenesis of a TPE is thought to be related to the rupture of a subpleural caseous focus in the lung into the pleural space. ${ }^{19}$ The basis for this is the observation by Stead et $a f^{20}$ of a caseous 
tuberculous focus in the lung contiguous to the diseased pleura in 12 out of 15 patients with tuberculous pleuritis. It is believed that delayed hypersensitivity plays a major role in the pathogenesis of TPE. The hypersensitivity reaction is initiated when tuberculous protein gains access to the pleural space.

TPE was found in $38.1 \%$ of our patients, the percentage of localization of pleural effusion indicates that the right pleural space is the most commonly involved and is observed in up to $64 \%$.

ESR is commonly used in the assessment of patients suspected of having tuberculosis. The ESR is regarded to reflect the activity of tuberculosis. In our study the ESR was found to be elevated in nearly $80 \%$ of the patients with a level between $11 \& 100 \mathrm{mml} / \mathrm{h}$, with nearly $46 \%$ of them have an ESR of more than $76 \mathrm{mml} / \mathrm{hr}$.

A study undertaken in Qatar ${ }^{21}$ to evaluate the utility of ESR in the diagnosis of childhood TB found that $33 \%$ of their cases had a normal ESR $(<10 \mathrm{~mm} / \mathrm{h})$ and $67 \%$ had elevated values (> 10 $\mathrm{mm} / \mathrm{h}$ ), and culture-positive TB cases had significantly higher ESR values than culturenegative cases. Our result can also be compared with a Danish study which has observed a normal ESR in $13 \% .^{22}$ So, overreliance on ESR may lead to failure to diagnose PTB, and this means that a normal ESR could be seen in an active PTB.

In conclusion, CXR is regarded as a very useful method for the diagnosis and in defining the location of PTB. The lesions have predilection to the right side so as the pleural effusion. The ESR is still useful in the diagnosis and follow-up of the activity of PTB.

\section{REFERENCES}

1. Ahmad Z, Zaheer MS. Lower lung field tuberculosis A clinical study. JIACM 2003; 4(2): 116-20.

2. Nwachukwu E, Peter G. Prevalence of Mycobacterium tuberculosis and human immunodeficiency virus (HIV) infections in Umuahia, Abia state, Nigeria. Afr J Microb Research 2010;4:1486-90.

3. Cowie RL, Escreet BC. The diagnosis of pulmonary tuberculosis. S Afr med 1980; I, 57,75.

4. Herchline T. Tuberculosis. [Cited July 2012]. Available from: URL: http:/emedicine.medscape.com/article/23038 02.

5. Yeldandi A. Pathology of Pulmonary Infectious Granulomas. [Cited July 2012]. Available from: URL: http://emedicine.medscape.com/article/2078678overview.

6. McGrath EE, Anderson PB. Diagnostic tests for tuberculous pleural effusion. Eur J CliMicrobiol infect Dis 2010;29(10):1187-93.

7. Porcel JM. Tuberculous pleural effusion. Lung 2009; 187(5):263-70.

8. Richter $C$, Perenboom R, Swai AB, et al. Diagnosis of tuberculosis in patients with pleural effusion in an area of HIV infection and limited diagnostic facilities. Trop Geogr Med. 1994;46(5):293-7.

9. Salazar-Lezama M, Quiroz-Rosales $H$, BañalesMéndez JL, et al. Diagnostic methods of primary tuberculous pleural effusion in a region with high prevalence of tuberculosis. A study in Mexican population. Rev Invest Clin 1997;49(6):453-6.

10. Blanc L. WHO Report 2002: Global Tuberculosis Control; surveillance, planning, financing. World Health Organization 2002. [Cited July 2012]. Available from: URL:http://www.hst.org.za/publication/who-report.

11. Van Dyck $P$, Vanhoenacker FM, Van den Brande $P$, et al. Imaging of pulmonary tuberculosis. EurRadiol 2003;13(8):1771-85.

12. Andreu J, Cáceres J, Pallisa E, Martinez-Rodriguez M. Radiological manifestations of pulmonary tuberculosis. Eur J Radiol 2004 Aug; 51: 139-49.

13. Pandya L, Al- Sharif N, Maraly MA. Lower lung field tuberculosis in Saudi Arabia. Am Saud Med 1990; 4; 374- 7.

14. Noertjojo K, Tam CM, Chan SL, Chan-Yeung MMW. Extra-pulmonary and pulmonary tuberculosis in Hong Kong. Inter J Tuber Lung Dis 2002;6(10):879-86.

15. Gonzalez OY, Teeter LD, Thanh BT, Musser JM, Graviss EA. Extrathoracic tuberculosis lymphadenitis in adult HIV seronegative patients: A population-based analysis in Houston, Texas, USA. Int J Tuberc Lung Dis. 2003;7:987-93.

16. Gonzalez OY, Adams G, Teeter LD, Bui TT, Musser $\mathrm{JM}$, Graviss EA. Extra-pulmonary manifestations in a large metropolitan area with a low incidence of tuberculosis. Int J Tuberc Lung Dis. 2003;7:1178-85.

17. Curvo-Semedo L, Teixeira L, Caseiro-Alves $F$. Tuberculosis of the chest. Eur J Radiol 2005; 55:158172.

18. Moudgil H, Sridhar G, Leitch AG. Reactivation disease: the commonest form of tuberculous pleural effusion in Edinburgh, 1980-1991. Respir Med. 1994; 88(4):301-4.

19. Timothy $B$, Philip A, Nigel T. A rapidly increasing pleural effusion. J R Soc Med 2004;97(1):5-26.

20. Basu A, Chakrabarti I, Ghosh N, Chakraborty S. A clinicopathological study of tuberculous pleural effusion in a tertiary care hospital. Ann Trop Med Pub Health 2012;5(3):168-72.

21. Al-Marri MR, Kirkpatrick MB. Erythrocyte sedimentation rate in childhood tuberculosis: is it still worthwhile? Int J Tuberc Lung Dis 2000; 4: 237-239.

22. Hussain M, Haque M, Arjum S, Ekram S, Rahman F. Extrapulmonary tuberculosis: Experience in Rajshahi Chest Disease Clinic and Chest Disease Hospital. TAJ 2004;17(1)16-9. 